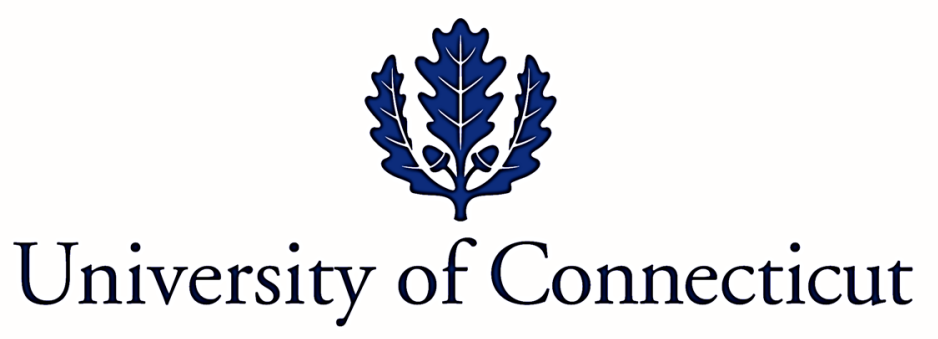

Department of Economics Working Paper Series

\title{
Religiosity: Identifying the Effect of Pluralism
}

by

Metin Coşgel

University of Connecticut

Jungbin Hwang

University of Connecticut

Thomas J. Miceli

University of Connecticut

Sadullah Y1ldırım

Ibn Haldun University

Working Paper 2018-19

October 2018

365 Fairfield Way, Unit 1063

Storrs, CT 06269-1063

Phone: (860) 486-3022

Fax: (860) 486-4463

http://www.econ.uconn.edu/

This working paper is indexed in RePEc, http://repec.org 


\title{
Religiosity: Identifying the effect of pluralism
}

By

Metin M. Coşgel ${ }^{*}$, Jungbin Hwang ${ }^{* *}$, Thomas J. Miceli ${ }^{* * *}$, and Sadullah Yıldırım

Revised October, 2018

\begin{abstract}
Economists and sociologists have long disagreed over the effect of pluralism on religiosity. The controversy stems from the omission of religion's role in legitimizing government, which has significantly biased previous estimates. We use a novel identification strategy that exploits the variation among countries in their proximity (cost of travel) to centers of universal religions of the world (Buddhism, Christianity, Islam). Whereas the results of OLS analysis tentatively suggest a negative association between pluralism and religiosity, estimates from the method of instrumental variables reveal that the direct effect of pluralism is positive. Our results support the argument that enhanced competition in the religion market would increase religiosity by offering believers a greater variety and quality of choices.
\end{abstract}

Key words: pluralism, religiosity, diversity, legitimacy, universal religion

JEL codes: Z12, H3, I1, O5, P5

Corresponding author: Metin M. Coşgel (Email: metin.cosgel@uconn.edu)

*Department of Economics, University of Connecticut, Storrs, CT 06269; Ph: (860) 486-4662;

Fax: (860) 486-4463; E-mail: metin.cosgel@UConn.edu

**Department of Economics, University of Connecticut, Storrs, CT 06269; Ph: (860) 486-2390;

Fax: (860) 486-4463; E-mail: jungbin.hwang@uconn.edu

*** Department of Economics, University of Connecticut, Storrs, CT 06269; Ph: (860) 486-5810;

Fax: (860) 486-4463; E-mail: thomas.miceli@UConn.edu

${ }^{\dagger}$ Department of Economics, Ibn Haldun University, Istanbul, Turkey; E-mail:

sadullah.vildirim@ihu.edu.tr 


\section{Religiosity: identifying the effect of pluralism}

\section{Introduction}

Scholars have long puzzled over the importance of religion in modern society. One of the most controversial questions in the social-scientific study of religion has been the effect of pluralism on religiosity. Sociologists of religion have traditionally argued that pluralism would undermine religiosity because a multiplicity of religions would reduce the plausibility of each belief (Berger, 1967). The advocates of an economic approach have challenged this view, arguing that pluralism would increase religiosity by enhancing competition among groups and offering believers a greater variety and quality of choices (Finke and Stark, 1988).

Despite the large number of studies devoted to this question, the results have been mixed and inconclusive. ${ }^{1}$ As Hungerman (2011: 258) notes, "confusion in the literature has stemmed from a number of overlooked theoretical and empirical problems," mainly due to the difficulty of identifying and estimating the direct effect of pluralism on religiosity. ${ }^{2}$ Although researchers have recently developed innovative identification strategies to analyze religious behavior, progress has been limited in applying these methods to estimate the causal effects of pluralism. The limitation comes primarily from the fact that pluralism is typically measured at the national level for cross-national analysis, hardly an ideal setting to mitigate endogeneity concerns through experiments or by analyzing differences-in-

\footnotetext{
${ }^{1}$ There have been numerous reviews and critiques of this literature. See, for example, Bentzen (2018), Chaves and Gorski (2001), Hungerman (2011), lyer (2016), and Voas, Crockett, and Olson (2002).

${ }^{2}$ Voas (2011) discusses the related difficulty of distinguishing influences on religiosity coming from the demandside and supply-side. See also lyer (2016: 417-22) for the problem of identification as the focus of most current empirical studies of religion. Benzten (2019) has recently used unpredictable earthquakes to identify differences in religiosity at the sub-national level.
} 
differences or regression-discontinuities. The broad coverage of cross-national analysis has also made it difficult for researchers to find suitable instruments for religious pluralism.

The source of endogeneity that we consider in this paper is the role of religion in legitimizing government, a social function likely correlated with both pluralism and religiosity. Throughout history, political leaders have used religion to bolster their power, such as by claiming to be divinely inspired or by forming alliances with religious leaders (Coşgel and Miceli, 2009). We would expect this support to be stronger in societies with highly concentrated religion markets because greater concentration would enhance the ability of religious leaders to act in unison in conferring legitimacy. To boost religious legitimacy, the rulers would thus likely subsidize the religion market in ways that would augment concentration. They would, for example, officially celebrate the holidays of only the dominant religion and likewise use public funds to sponsor only the dominant religion's clergy, buildings, and activities. Since these expenditures would ultimately serve to advance religious behavior and participation in the population, we would expect religiosity to rise as well. Hence, if researchers overlook the importance of religion in serving as a legitimizing force for political leaders, they would derive biased estimates of the effect of pluralism on religiosity because of omitted variables.

This paper proposes to address endogeneity concerns by developing a simple model of religiosity that clarifies the direction of the omitted variable bias and to identify the causal effect of pluralism by using a novel instrumental variable. For a quantitative analysis of the model's implications, we use a pooled cross-sectional dataset that includes indicators of religiosity from the World Values Survey (1981-2014), measures of pluralism for years that correspond to the surveys, and several other variables that consider the effects of age, gender, and religious affiliation of individuals and the geographic characteristics of nations. We first run Ordinary Least Squares (OLS) analysis to generate benchmark estimates of influences on religiosity, which we use to compare against those previously obtained in the literature and to determine the direction of the omitted variable bias. To mitigate the bias, we use an 
instrumental variable that exploits the variation among nations in the cost of travel (walking time) to the "capitals" of the universal religions of the world (Buddhism, Christianity, Islam).

The OLS results reveal a negative and highly significant effect of pluralism on religiosity for some measures, which accords with the sociological view. When we mitigate the omitted variable bias through the method of instrumental variables, however, we find that the direct effect of pluralism generally goes in the opposite direction. The coefficient of pluralism obtained by the Two Stage Least Squares analysis is consistently positive and significant for all measures of religiosity, supporting the model's implication that the omission of the legitimizing function of religion imparts a negative bias in the simple OLS analysis of the effect of pluralism on religiosity. In terms of theory, our results support the economic argument that pluralism has had a positive effect on religiosity.

Since our empirical analysis relies heavily on the credibility of the instrument, we perform various robustness checks on the first and second stages. We estimate additional specifications of the baseline model to see how the first and second stage results change based on the inclusion and exclusion of control variables. For another check of robustness, we run reduced form regressions that directly relate the instrumental variable to measures of religiosity. In addition, since the results might be sensitive to the selection of surveyed countries, we estimate the model with various subsamples of the data. Finally, we perform a falsification test to determine whether the travel cost to various other cities, such as Lagos, New York, São Paulo, Sydney, and Tokyo, which are currently important regional centers but have no religious significance, explains religious pluralism. The results of these robustness checks support the credibility of our instrument.

Our analysis provides the first unbiased estimates of the causal effect of pluralism on religiosity. Previous results have been mixed and inconclusive, not just because the observed effects of pluralism on religiosity have varied across studies depending on context and data, but because the unobserved 
effect of pluralism has also varied due to the omitted legitimizing function of religion. In addition to improving upon previous studies, our approach reconciles conflicting results by identifying the direction of the bias, and it offers a way to move forward by prompting future researchers to explore other identification strategies with the objective of improving estimates and determining the net causal effect of pluralism in varying contexts.

\section{Religiosity: A Simple Model}

Recent work on the connection between religious pluralism, or fragmentation of the religion market, and religiosity has identified competing theoretical predictions regarding this relationship. Sociologists have traditionally argued that a monopolistic (concentrated) religion market is conducive to a high level of religiosity by citizens. Any fragmentation of the market, the argument goes, will dampen religious enthusiasm by reducing the plausibility of the dominant religion (see, for example, Berger, 1967). More recent scholarship, however, has challenged this view. Authors like Finke, lannaccone, and Stark contend that a monopolized religion market will lack the diversity of options and innovative practices that are necessary to attract and retain loyal adherents (Finke and Stark, 1988; lannaccone, Finke, and Stark, 1997). Thus, they argue, "where religious monopolies prevail, the overall level of public religious involvement will be low" (Stark, 2007, p. 121). ${ }^{3}$

Taken together, these arguments suggest an ambiguous relationship between a measure of religious fragmentation, $F$, and religiosity, $R$. But as Hungerman (2012) points out, a simple regression of $R$ on $F$, apart from measurement problems, is also likely plagued by an omitted variable bias. He refers vaguely to such factors as "history" and "culture" that are possibly correlated with both $F$ and $R$.

\footnotetext{
${ }^{3}$ This view resurrects arguments made by Adam Smith, as discussed by lannaccone (1991). See also Franck and lannaccone (2014) for a recent test of alternative theories of religious change.
} 
Recent work on the role of religion as a legitimizing agent for governments suggests a more specific source of this bias, as well as its direction. Scholars have recently identified the legitimizing ability of religion as a key explanation of numerous historical and current institutions, policies, and outcomes. Historically, the manner by which religious leaders increased the legitimacy of a government was by declaring the sovereign divine, or at least with a divine right to rule. Researchers have shown how the legitimizing relationships between religious and political authorities have influenced historical phenomena, such as in the adoption of state religion, delayed acceptance of the printing press, interest restrictions in Islam and Christianity, and the divergent experiences of England and the Dutch Republic as compared to Spain and the Ottoman Empire in economic development. ${ }^{4}$

In modern times, the mechanism more likely takes the form of praising governmental policies and leaders from the pulpit, offering moral support for political authorities, and/or the holding of governmental positions by religious officials. As Fox (1999: 289) notes, "[o]ne of the few truisms in the study of politics that seems to have near universal acceptance is that religion can bolster the legitimacy of both governments and opposition movements". Studying contemporary processes of legitimization, researchers have shown the important role of religious legitimacy in modern societies, such as in influencing grievance formation by minorities, structuring moral and cultural values, and affecting the impact of sanctions on a regime's policies and behavior. ${ }^{5}$

If we omit the role of religious legitimacy in empirical analysis of the relationship between $F$ and $R$, the results could be biased because religious legitimacy might be correlated with both $F$ and $R$. To illustrate, let $L$ denote an index of the importance of religion for legitimizing government, where higher $L$ denotes greater importance. $L$ might be correlated with $F$ because a more concentrated (less

\footnotetext{
${ }^{4}$ See, for example, Cosgel and Miceli (2009), Cosgel, Miceli, and Rubin (2012a,b), and Rubin (2017).

${ }^{5}$ See, for example, Kokosalakis (1985), Fox (1999), and Naghavi and Pignataro (2015).
} 
fractionalized) religion market will be more conducive to enhancing legitimacy by allowing religious leaders to speak with a single voice. Thus, we posit the following relationship between $F$ and $L$ :

$$
L=g(F)
$$

where $g^{\prime}<0$.

We also suppose that $L$ has a direct effect on $R$, independently of its dependence on $F$. In particular, we suppose that societies in which religion plays a large role in legitimizing the government will also tend to have greater religiosity, all else equal. In such societies, we would expect governments to invest in religious legitimacy by subsidizing this relationship, for example through formal ceremonies and official funds allocated to the construction of religious buildings and monuments. Consequently, we would expect these investments to promote greater religiosity. ${ }^{6}$ This reflects a supply-side effect of $L$ on $R$, taking $F$ as given. In other words, regardless of the organization of the religion market, a government that relies on religion to confer legitimacy on it will have an incentive to promote religiosity among its citizens in order to maximize the exposure of citizens to the praise of religious leaders.

The foregoing suggests that the religiosity function can be written as

$$
R=f(F, L)
$$

where $f_{F}$, the partial direct effect of fractionalization of the religion market, has an ambiguous sign based on the competing theories described above, while $f_{L}>0$ based on the preceding argument. Substituting (1) into (2) and taking the total derivative of $R$ with respect to $F$ yields

$$
d R / d F=f_{F}+f_{L} g^{\prime},
$$

\footnotetext{
${ }^{6}$ McCleary and Barro (2006: 161) make a similar argument to explain the positive effect of subsidies on religiosity under state religion.
} 
where $f_{L} g^{\prime}<0$. It follows that a simple regression of $R$ on $F$ will yield an estimate of (3), whereas the effect we want to estimate as a way of testing the competing theories is $f_{F}$, the marginal impact of $F$. The omission of $L$ from the regression equation thus imparts a negative bias to the estimated magnitude of $f_{F}$.

\section{A Preliminary Empirical Analysis of Religiosity}

\section{3.a. Empirical Model and Data}

For an empirical investigation of the effect of pluralism on religiosity, we first estimate the following equation:

$$
R_{\mathrm{ict}}=B_{0}+B_{1} F_{\mathrm{ct}}+\boldsymbol{X}_{\mathrm{ict}}^{\prime} \boldsymbol{B}_{2}+\varepsilon_{\mathrm{ict}}
$$

where $R_{\text {ict }}$ is the religiosity level of individual $i$ in country $c$ at time $t, F_{\text {ct }}$ is a measure of religious pluralism (fractionalization) in country c at time $t$, and $\boldsymbol{X}^{\prime}$ ict is a vector of individual level and country level control variables.

To measure religiosity, we use the World Values Survey (WVS), which includes individual level data for up to 98 countries in six waves covering the period between 1981 and 2014 . Table 1 shows the numbers of countries surveyed in each wave and the distribution of these countries by main religion. Because our identification strategy will be focused on missionary/universal religions (Buddhism, Christianity, Islam), the table itemizes these religions. The residual category called "Other" includes Chinese folk religion, Hinduism, Judaism, Shinto, and non-religion. Although the surveys included only a small number of countries in the first two waves, the numbers increased substantially thereafter, and the mix of main religions represented in the samples became more diverse. The first wave included only 8 countries, 6 of which adhere to Christianity as the main religion, 1 to Buddhism, and 1 Other. By the last wave, the surveys covered 60 countries, with 3 adhering to Buddhism, 29 to Christianity, 20 to Islam, and 8 to others as the main religion. 
Table 1 about here

Whereas some of the questions in the WVS were related to an individual's broad perceptions regarding important things in life, others probed specific views regarding the environment, work life, or national identity. The surveys include several questions regarding religious values and behavior, which social scientists have used as indicators of religiosity (e.g., Bentzen, 2019; McCleary and Barro, 2006; Norris and Inglehart, 2004). For example, the surveys asked respondents broadly whether they were a "religious person" or considered religion as "important in life," and specifically whether they participated in certain religious activities and considered religion as an important factor in decisions regarding family, politics, community, and moral values.

For a robust empirical analysis of religiosity, in place of a single indicator we chose a representative subset of five WVS questions commonly used by researchers as indicators of various aspects of religious belief and behavior. ${ }^{7}$ Although the WVS includes numerous questions with substantial detail regarding religiosity, we had to exclude some of them from our comprehensive analysis because they were available for certain waves and countries but not for others, or were relevant for only certain cultures and religious traditions but not for many others. ${ }^{8}$ The survey questions included in our analysis are those that asked respondents whether they a) considered religion important in life, b) had membership in a church or religious organization, c) attended services regularly, d) were a religious person, and e) believed in God. Since these questions do not have standard answers, we standardized and recoded the

\footnotetext{
${ }^{7}$ In a previous version of this paper, we constructed an index of religiosity based on factor analysis that identified the dimensions of data and clusters of questions from which we chose a smaller subset of these variables for a coherent measure of religiosity. The results were consistent with those found in this version for a broader set of variables reported individually and in the aggregate.

${ }^{8}$ Details on questions and coverage can be found on the WVS website: http://www.worldvaluessurvey.org
} 
responses to vary between 0 and 1 in increasing levels of religiosity. In addition, we calculated the mean score of the responses to these five questions for an overall index of religiosity.

Figure 1 about here

Figure 1 shows the evolution of average religiosity over time in countries that were included in the WVS as categorized by the main religions. To the extent that the surveyed countries are representative of these categories, we observe interesting patterns in the way religiosity differed across religious traditions. In all surveys, religiosity was consistently the highest in countries with mainly Muslim populations. Religiosity was also high in countries with mainly Christian populations, as compared to those populated mainly by adherents of Buddhism and other religions.

For an indicator of religious pluralism, we calculated the index of fractionalization (1-Herfindahl Index) for each country and time-period by using annual data on the percentage shares of the populations of religious groups (Brown and James, 2015). As a novel feature of our analysis, whereas previous studies using pooled data have typically considered religious pluralism to be fixed over time, we calculated time-varying measures of fractionalization corresponding to different waves of the Survey, which we believe is more appropriate for this analysis because of the significant shifts in the religious distribution of populations that happened through conversion and migration during this period. ${ }^{9}$ Figure 2 shows the geographic distribution of the index of religious fractionalization in the world in the year 2010.

\footnotetext{
${ }^{9}$ McCleary and Barro (2006), for example, use the year 1970's distribution of religious populations to calculate the measure of fractionalization.
} 
Figure 2 about here

Voas, Olson, and Crockett (2002) have criticized the use of a fractionalization measure as a determinant of religious participation because in studies that define participation through simple affiliation, the result would reflect a mechanical link between pluralism and participation rather than a causal relationship. This criticism does not apply to our analysis because our measure of religiosity does not depend on the fraction of affiliated population.

To isolate the effect of pluralism on religiosity, we control for variables that researchers have argued have significant influences on religiosity. The first set of controls are individual level variables, namely age, gender, and (arguably exogenous) religious affiliation. Regarding the latter, given our emphasis on universal religions, we use the information from the World Values Survey regarding affiliation to generate four dummy variables that code whether the surveyed individual was Buddhist (equals one if true), Christian, Muslim, or other (including those with no religious affiliation). In regression analysis, we omit the "other" variable to provide the reference category so that the coefficients of universal religions show the differential effect compared to other (or non-) affiliations.

As another novel feature of our analysis, we control for various geographic characteristics of countries. In the recent literature on economic growth and development, researchers have shown that differences in geographic characteristics of countries can have a significant impact on socio-economic behavior, institutions, and performance. ${ }^{10}$ Some of the geographic characteristics of the religion market,

\footnotetext{
${ }^{10}$ See, for example, the works included in Michalopoulos and Papaioannou (2017).
} 
such as its size and relationship to other markets, might affect religiosity. We include the total land area of a country and its landlocked status to control for these effects.

Our main motivation for including certain other geographic variables is to address a threat to the credibility of using the cost of travel (walking time) to the birthplaces of universal religions as an instrument for religious pluralism (detailed in the next section). The concern is that there might be a direct association between these locations and religiosity, which is likely if universal religions emerged in places of certain characteristics. For example, Cesur and Yıldırım (2018) have recently uncovered a strong link between religion and population diversity based on Durkheim's (1912) argument relating the emergence of religion to the need for cooperation. Taking population diversity as a proxy for the need for cooperation, they adopt Ashraf and Galor's (2013) strategy of identifying diversity through the migratory distance of a settlement to the cradle of humankind in East Africa, known as the "Out of Africa" hypothesis. Since the implied direct link between these locations and religiosity would cast doubt on the credibility of our instrument, we mitigate this potential concern by including the distance to East Africa as a covariate in both the first and second stage of our analysis, a strategy adopted from Dee $(2004) \cdot{ }^{11}$

In the same vein, we include several other geographic variables in our analysis to mitigate similar potential concerns regarding the exclusion principle. For example, religiosity in the birthplaces of universal religions may have been related to geographic characteristics of these locations in climate, terrain, and suitability for certain economic activities. Therefore, we include the average precipitation and temperature in a country and measures of terrain roughness and land suitability for agriculture as

\footnotetext{
${ }^{11}$ In a similar setup, Dee (2004) used proximity to two-year colleges as an instrument for enrollment in his analysis of enrollment's effect on civic engagement. He included various covariates, including county-level variables, to address the same threat to the credibility of his instrument due to the violation of the exclusion principle. See also Murnane and Willett (2011: 238-43) for a general discussion of how the inclusion of exogenous covariates, such as geographic variables, into instrumental variable estimation helps to address this concern.
} 
covariates. ${ }^{12}$ By carefully choosing covariates that will be included in both the first and second stage, we are able to control for other associations that could have otherwise linked the instrument directly to religiosity. For consistency, we include the same variables in the OLS analysis.

Finally, we include categorical variables to control for the systematic differences among the different waves of the WVS. Appendices A and B report the summary statistics of these variables.

\section{3.b. Baseline OLS Analysis of the Effect of Pluralism on Religiosity}

We now use the data for a regression analysis of the model's empirical implications regarding the effect of pluralism on religiosity. To recap, the dependent variables in this analysis are the six indicators of religiosity constructed from the WVS as previously described. The key independent variable of interest is religious pluralism, measured by an index of fractionalization. In addition, our analysis includes individual characteristics (age, gender, religious affiliation), country level control variables, and WVS wave dummies. To obtain baseline results for comparison, in this section we run OLS regressions. Since this formulation may suffer from endogeneity problems regarding omitted variables (detailed below), in the next section we will use an instrumental variables approach to address these concerns. Given that the data in both analyses are grouped into clusters of countries and WVS waves, we use twoway clustering by defining groups at the country*wave level.

Table 2 about here

\footnotetext{
12 These data come from Michalopoulos (2012) and Ashraf and Galor (2013), which include information regarding the definitions, construction, and original sources of these variables.
} 
The baseline OLS results reported in Table 2 show a negative effect of pluralism on four of the six measures of religiosity, and the negative effect is highly significant for two measures. Seemingly an exception to the pattern, pluralism's effect on membership of religious organizations is positive and significant, indicating that the value of belonging to a religious organization and formal membership increases in more plural environments. Note, however, that the number of observations that generated this result in Model 2 was significantly lower $(220,786)$ than in the overall sample $(306,620)$. The question was not asked in over a quarter of the surveyed countries, simply because membership in a church or a religious organization does not have the same connotation in all religious traditions, and thus is not a consistent measure of religiosity. The insignificance of the coefficients of "Muslim" and the lower coefficient of "Buddhist" in the second column shows the reduced importance of such membership in these religions. Hence, although the positive and significant coefficient of membership seems to be an exception, this result may still be consistent with pluralism's negative effect on other measures of religiosity. All in all, the OLS estimates reported in Table 2 seem to support the traditional sociological view that the multiplicity of religions would reduce religiosity by undermining the plausibility of each belief, a tentative result that we scrutinize below.

Table 2 shows interesting results regarding the effects of other independent variables on religiosity. Age and being female generally has positive effects on religiosity, as expected. Adherents of universal religions are more religious than others (including non-believers) in most measures of religiosity, again as expected. Geographic variables and dummy variables for the waves of WVS control for geographic characteristics of countries and systematic variations in religiosity across surveys. 


\section{Addressing Endogeneity Concerns}

The OLS estimates of the coefficient of religious pluralism would have a causal interpretation only if the assumed specification of the empirical model includes all of the relevant explanatory variables, with no doubts regarding the exogeneity of pluralism. But if we leave out a variable that can affect pluralism as well as religiosity, we should suspect the coefficient of pluralism to be biased. As we detailed in the theoretical model, a variable that can cause such bias if omitted from analysis is the legitimizing role of religion. Unfortunately, we are unable to include this variable directly in the empirical analysis because we lack comprehensive cross-national data on the ability of religion to legitimize political rulers. Although the WVS includes questions on people's confidence in religious leaders and whether these leaders should influence how people vote, no questions probe directly their views on the importance of religion to legitimize government. We thus need to adopt an appropriate identification strategy to ascertain the causal effect of pluralism on religiosity.

We propose to use an instrumental variable for pluralism to mitigate the omitted variable bias. ${ }^{13}$ For a strong predictor of the degree of competition in a country's religion market, we exploit spatial information regarding the country's proximity to religious centers, more specifically the "cost of travel" (walking time) to the birthplaces or spiritual centers of missionary/universal religions of the world (Buddhism, Christianity, Islam). Although economists have recently used distance as an instrumental variable in various types of empirical research (e.g., distance to nearest school as an IV for education), we believe this is the first paper in empirical analysis of the relationship between pluralism and

\footnotetext{
${ }^{13}$ See Hungerman (2012) for a different identification strategy that uses the availability of secular alternatives to religion as an instrumental variable. Focusing on the endogeneity between GDP and religiosity, McCleary and Barro (2006) use exogenous geographical features of countries as instruments but find minor changes in the estimated coefficient of GDP after mitigating the bias.
} 
religiosity that exploits differences in the cost of travel from each country to the centers of missionary religions as an instrument for concentration in the religion market. ${ }^{14}$

Consistent with other identification strategies based on spatial information, this instrument works by recovering predicted concentration from the travel cost to the main provider. As we detail below, it is based on the observation that universal religions increasingly dominated religious markets over time by progressing linearly from their centers to other regions. Regarding differences between countries, our hypothesis is that the costlier it is to travel from a country to centers of universal religions, the higher will be the pluralism in its religion market due to the restricted dominance of these religions. Using the travel cost to the nearest universal religious center as an instrument for pluralism, we use Two Stage Least Squares (2SLS) analysis to identify the direct effect of pluralism on religiosity.

Scholars of religion have long used the concept of universalism to classify religions. Nineteenth century pioneers of comparative religion typically identified Buddhism, Christianity, and Islam as belonging to the category of universal (or missionary) religions. This is to be distinguished from Hinduism, Zoroastrianism, and numerous other non-universal religions that are limited to a particular people or region. ${ }^{15}$ The distinction has endured in the study of religion, as can be seen in current textbooks on the history of religions and in entries in the Encyclopedia of Religion (Bianchi, 1987). ${ }^{16}$ The universal religions of the world have been considered as distinct from others "because they are not linked to blood, racial, ethnic, or national groups, and anyone can join them." In addition, these religions

\footnotetext{
${ }^{14}$ For examples of distance as an instrument for education, see Card (1995) and Dee (2004). To our knowledge, Stark (1991) is the first scholar to use distance as a variable in empirical analysis of religion, specifically in the rise of Christianity among Greco-Roman cities. Cantoni (2012) finds the distance to Wittenberg to be a significant determinant of the adoption of Protestantism. On the expansion of Islam, see Michalopoulos, et al. (2018). See also Ashraf and Galor (2013) for the relationship between human genetic diversity and the distance from the cradle of humankind in East Africa.

${ }^{15}$ See, for example, Introduction to the Science of Religion by Max Müller (1873), often considered the "Father of the history of religions," and his lectures on the subject at the Royal Institution (1870) and Westminster Abbey (1873). In the same vein, Kuenen (1882) distinguished between "National Religions" and "Universal Religions" in his Hibbert Lectures.

${ }^{16}$ See also Sharma (2012) and Johnson and Johnson (2007) for recent discussions.
} 
share the distinct characteristics of delivering a message of salvation that appeals to everyone, making the faith "accessible to people far from where it originated." (Johnson and Johnson, 2007: 6-7).

Although religions could be classified along various other criteria, we believe that universalism is the most relevant characteristic in analyzing market shares and pluralism. In the study of religion and religious history, scholars have classified religions based on their object of worship, otherworldliness, historical evolution, and various other criteria including ethnic, temporal, and geographic origin. Though useful for other purposes, these characteristics do not provide sufficient information regarding a religion's ability to expand its market share. Universalism is a useful concept for our purpose because of the obvious limitation that non-universal religions impose on their shares by restricting membership to a specific ethnic, geographic, or other exclusive group. By welcoming others to join, in contrast, universal religions have managed to increase their share and indeed keep expanding geographically into other markets though migration, trade, conquest, exploration, and missionary activities aimed at converting others.

For a measure of travel cost, we use the walking time from the center of the nearest universal religion to each country's capital city. The advantages of our approach in using walking time/distance rather than the aerial distance, which has been typically used in the recent literature (Ashraf and Galor, 2013; Coşgel et al, 2018), is that walking mode of travel incorporates variations in topography and obstacles on the way. Moreover, by using walking time rather than walking distance we are able to incorporate differences in elevation between two points and other factors that depend on the direction of travel. Note also that we opted for a measure based solely on the travel cost to the nearest universal religion rather than more complicated measures that could consider other religious centers because of its simplicity and the strength of its first stage results presented below. 
The specific centers used for our calculations are Lumbini, Nepal (Buddhism); Wittenberg, Germany (Protestanism); Istanbul, Turkey (Orthodox Christianity); Karbala, Iraq (Shia Islam); Mecca, Saudi Arabia (Sunni Islam); and Vatican City (Roman Catholicism). These are the centers of universal religions or their sub-branches that have historically expanded out from their birthplaces, eventually becoming main religions in other territories. ${ }^{17}$ To calculate travel time across continents, we required routes to go through the following waypoints: Cairo, Egypt (Africa-Asia), Istanbul, Turkey (Asia-Europe), Phnom Penh, Cambodia (Asia-Oceania), Palos de la Frontera, Spain (Europe-Western Hemisphere), Santa María la Antigua del Darién, Columbia (Europe-South America) and Tenochtitlan, Mexico (EuropeCentral and North America). The first three of these waypoints are based on Ramachandran et al. (2005), and the latter three are based on historical information regarding the starting location of European overseas exploration and the first sites of European conquest in the southern and central/northern sections of the Western Hemisphere (i.e., two sites because of the Darién Gap). ${ }^{18}$

Figure 3 about here

\footnotetext{
${ }^{17}$ Scholars of religion may disagree with our choices of centers. For example, some may argue that Bodh Gaya, India should be considered as the center of Buddhism because it is the place where Gautama Buddha is said to have obtained Enlightenment. We do not wish to state a strong position on this debate because our results do not change significantly when we change the center of Buddhism from Lumbini to Bodh Gaya in our calculations. While we acknowledge controversies regarding centers of religions, we have made informed but pragmatic choices of locations that best serve the purpose of identification.

${ }^{18}$ For information regarding the travel time and distance from these centers to each country, we used Python script to retrieve the data from Google server. Since Google currently does not provide data for routes through China, we used Bing to calculate the walking distance from China and in routes from Mongolia, Japan, Taiwan, and South and North Korea going through China. Whenever the route from a country to a religious center inevitably involved travel through a body of water, we used the average walking equivalent ( $5 \mathrm{~km}$ per hour) to incorporate this segment in our calculations. This questionable approximation is roughly consistent with the amount of time (about two months) that Columbus took to cross the Atlantic in his first voyage (about 6,500 km).
} 
The distinct impact of universal religions in shaping pluralism in modern societies can be seen from the enormous expansion that they experienced over time at the expense of others. Although we lack comprehensive historical data on the population shares of all religious groups in the world, we can look at the transformation of main religions over time for a snapshot of the growing dominance of universal religions. For this analysis, we use the "Historical Polities Data," which includes annual information on the territories corresponding to the boundaries of today's nation states since the year 1000 (Coşgel, 2016). In the year 1000, the main religion was universal in only 93 (38\%) of the 246 territories that comprise the dataset. By the year 2000, however, the fraction rose tremendously to $91 \%$ of the territories. For a more comprehensive geographical depiction of this transformation, Figure 3 shows for each territory the fraction of years in which the main religion was universal during the period between 1000 and 2000. The darker shades correspond to a higher fractions of years with universal main religions. Clearly, the lands closest to the centers of universal religions have generally had the longest durations dominated by universal main religions as compared to the lands farther from these centers. By offering a visual illustration of our identification strategy, the map shows how the distance and travel cost to centers of universal religions impacted pluralism in religion markets.

To instrument religious pluralism by travel cost to centers of missionary religions, we estimate the following first stage equation:

$$
F_{\mathrm{ct}}=\gamma_{0}+\gamma_{1} T_{\mathrm{c}}+\boldsymbol{X}_{\mathrm{ict}}^{\prime} \boldsymbol{\gamma}_{2}+u_{\mathrm{ict}}
$$

where $T_{\mathrm{c}}$ is the travel cost (walking days) from the centroid of each country to the nearest missionary center. Other variables are as defined in (4) above.

Table 3 about here 
The first stage results are reported in Table 3. The coefficient of travel cost is positive, as expected, indicating that concentration was higher in markets closer to centers of universal religions, and that pluralism rose as the cost of travel increased. The results regarding the effects of geographic characteristics on religious pluralism are also interesting. Migratory distance from the cradle of civilization had a negative effect on religious pluralism, consistent with the findings of Cesur and Yıldırım (2018) discussed earlier. The total land area of countries also had a positive effect on pluralism, indicating that larger countries were better able to accommodate diversity. Whereas average precipitation and temperature affected pluralism significantly, land suitability, terrain roughness, and having a landlocked status had no significant effects.

Regarding the relevance of our instruments, the results show that travel cost to universal religions is a strong instrument for religious pluralism. Overall, the exogenous variables explain $44 \%$ of the variation in religious pluralism, and the $F$ statistics for the excluded instrument is 113.85 , highly significant. Although religious diversity may be determined by a host of other factors (e.g., conversion, conquest, migration - many of which are unobservable), our results show that the travel cost to centers of universal religions is perhaps a crude but nevertheless a highly relevant instrument with a strong signal.

We make a two-fold argument that the exclusion principle is satisfied. We argue that the condition must be inherently satisfied for current societies because there is conceptually no direct association between religiosity and proximity to centers of universal religions. Notice, for example, the high levels of religiosity observed in the modern Western Hemisphere as evidence of the current insignificance of proximity to historical religious centers (Norris and Inglehart, 2004: Chapters 3 and 4). This argument does not entirely address concerns regarding the exclusion principle, however, because it 
does not rule out the possibility of an unobserved direct relationship between religiosity and travel cost to centers of universal religions, through historical and other channels. The credibility of our instrument would be in question if universal religions emerged in places of certain characteristics, such as through the link recently found by Cesur and Yıldırım (2018) between religion and population diversity, and if we did not address this threat appropriately.

For a stronger case in justifying the credibility of our instrument, we included covariates in our analysis that effectively control for the possible associations between centers of universal religions and religiosity, as noted in the previous section. To recap, our analysis includes as covariates (in both the first and second stages, as well as the OLS analysis for consistency) the distance to East Africa and the average precipitation and temperature in a country, and measures of terrain roughness and land suitability for agriculture. Including these variables in the analysis allows us to argue that, among individuals in countries that were equidistant to the cradle of civilization, and had the same geographic characteristics in climate, terrain, and suitability for economic activities, there was no direct link between proximity to centers of universal religions and religiosity. This approach to identification supports the credibility of our instrument by eliminating unobserved direct effects on religiosity.

We extended the first stage model in two ways to check the sensitivity of our results to variations in the levels of data and the temporal specification of the instrument. Although pluralism is measured at the country level, in producing the results reported in Table 3 we had used individual-level observations for consistency with the second stage analysis. To check whether the results are sensitive to level of data, we reran the same analyses with aggregated data for countries. We calculated the means of age, gender, and religious affiliation at the country-level for each wave so that the resulting data have (unbalanced) panel structure with countries and the six waves of the WVS as the unit of analysis. The results of country-level analysis (details available upon request) are consistent with those reported in Table 3 with individual-level data. The coefficient (standard error) of travel cost rose 
somewhat to $0.00538(0.000987)$, still positive and highly significant. Although the $F$ statistic for excluded instrument fell to 45.13 , it is still highly significant.

For another extension of the basic first stage model, we considered a different specification of the instrument to allow for temporal changes in the relationship between travel cost and religious pluralism. More specifically, we included the interaction of travel cost to missionary centers with the dummy variables for the WVS waves. The results of first and second stage analyses, detailed in the last section (Panel $D$ in Table 5) below, show that it makes little difference whether the interaction terms are included in the model.

\section{An Instrumental Variable Estimation of the Effect of Pluralism on Religiosity}

The second stage results of the instrumental variables method of estimation show that the causal effect of pluralism on religiosity is in the opposite direction of the negative estimates obtained by the OLS analysis, and that the magnitude of the positive effect of pluralism on membership (column 2) is vastly higher than the OLS estimate. As detailed in the previous section, we used the travel cost to centers of universal religions as an instrumental variable for religious pluralism, and we applied the 2SLS method to mitigate the omitted variable bias and to appropriately identify this variable's direct effect on religiosity. As seen in Table 4, the direction and magnitude of the effect of age, gender, and religious affiliation stayed about the same across the two methods. The biggest change is in the effect of religious pluralism. The coefficient of this variable is now uniformly positive, contrary to the negative coefficients obtained by the OLS method (Table 2).

The Sargan's statistic (equivalent to Hansen's J statistic in this case because of robust standard errors) reported in Table 4 allows us to test for the validity (exogeneity) of our instruments; namely, the condition that these variables must be orthogonal to the error process. As seen from the $p$-values of the 
Sargan statistics, we fail to reject the null hypothesis of orthogonality at conventional size of the test, say one percent, which provides statistical confidence to the validity of our instruments and boosts confidence in their employment in this analysis.

Table 4 about here

The difference between the OLS and 2SLS estimates of the coefficients of religious pluralism confirms the negative direction of the omitted variable predicted by the theoretical model. Whereas the 2SLS estimate of the coefficient of the Religiosity Index (column 5) is 0.468 , the OLS estimate was -0.008 , a decrease of 0.476 . In the same vein, the bias calculated from the change of coefficients between the two sets of estimates is 0.511 for "Important in Life: Religion," 0.741 for "Membership of church or religious organization," 0.485 for "How often do you attend religious services," 0.244 for "Religious person," and 0.368 for "believe in God," all large enough magnitudes to reverse the results of negative OLS estimates. To reiterate, we argue that the differences are caused by the omission of the legitimizing function of religion from the OLS analysis.

Our results shed new light on the literature by providing consistent estimates of the direction of the effect of pluralism on religiosity that ultimately support the economic approach. Whereas the OLS estimates, when plagued by the negative omitted variable bias, seemed to provide strong support for the traditional view that greater pluralism undermined religiosity by reducing the plausibility of dominant beliefs, the 2SLS results revealed the more complicated nature of this relationship. By mitigating the omitted variable bias appropriately, we have found the direct effect of religious pluralism on religiosity to be positive, supporting the contention that enhanced competition and greater variety and quality of choices increase religiosity. In addition to supporting the advocates of an economic 
approach to the relationship between pluralism and religiosity, our results help to explain why the findings of previous studies have been inherently mixed and inconclusive due to the changing magnitude of the omitted variable bias in different contexts.

\section{Robustness Checks}

The empirical confirmation of our argument regarding the effect of pluralism on religiosity clearly depends on the credibility of using the travel cost to centers of missionary religions as an instrument for religious pluralism. In this section, we perform various robustness checks on the first and second stages of the analysis to confirm the credibility of our instrument. We specifically test whether our main results are sensitive to variations in the specifications of the empirical model, direct inclusion of the instrument in reduced form, subsamples of data, and (placebo) centers of religion.

First, we observe the change in the coefficient of religious pluralism in different specifications of the model based on the sequential inclusion of control variables in both the first and second stages and on the expansion of the instrument's relationship with religious pluralism by including interaction terms with temporal variables. Table 5 shows four different variations of the model in separate panels. All panels include the dummy variables for the waves of the WVS. Whereas the first panel includes the baseline model with the same set of explanatory variables as in Table 4, we additionally include the per capita Gross Domestic Product (GDP) and state religion in Panel B, and we include only geographic variables (i.e., drop GDP, state religion, and individual characteristics--namely age, gender, and religion), in Panel C. Finally, in Panel D we expand the specification of the instrument to allow for temporal changes in the relationship between travel cost and religious pluralism by including the interaction of travel cost with the dummy variables for the WVS waves. 
The reason for the inclusion of GDP and state religion in Panel B is to compare our results with previous studies. Despite potential concerns regarding the exogeneity of GDP, this variable has received substantial attention in the literature as an indicator of economic development and modernization. ${ }^{19}$ Another (potentially endogenous) factor commonly considered in studies of religiosity is the state control of religion, typically operationalized through a dummy variable based on the presence of state religion (=1 if the country had a state religion) during the time of each survey (North and Gwin, 2004). Although this variable might compensate to a certain extent for the omission of religion's ability to legitimize government, we believe that it is an imperfect proxy. Some countries, such as the United Kingdom or Scandinavian countries, do not heavily promote religiosity or seek to influence religious concentration, despite having state religions. Governments in other countries without an official religion, such as Turkey, by contrast, implement policies that may influence religiosity and concentration. Given the additional endogeneity concerns regarding GDP and state religion, we excluded these variables from our baseline analysis, but include them here for comparison with other studies and to ensure that our results do not depend on their exclusion.

Table 5 about here

The figures in Table 5 show the coefficients and standard errors of the effect of religious pluralism on the dependent variable listed in the top row. We used 2SLS analyses to estimate the coefficient and standard error of pluralism separately for each equation corresponding to the set of control variables stated in the panel's description. The results remain generally consistent across the four different

\footnotetext{
${ }^{19}$ See, for example, Norris and Inglehart (2004) and McCleary and Barro (2006). The source of GDP and population data is Version 8.1 of Penn World Tables.
} 
specifications of the model. Although the coefficients and standard errors of pluralism obviously vary across panels, the effect of this variable on different measures of religiosity is always positive, and significant at the one percent level in all but one cases.

Although not reported in the Table (but is available upon request), we have found the coefficient of per capita GDP to be negative and mostly significant, consistent with previous results regarding the effect of economic development on religiosity (McCleary and Barro, 2006). Among the unreported first stage results, the coefficient of travel cost (available upon request) is always positive and highly significant, providing strong confidence that the instrument is robust to different specifications of the model. This can also be seen from the $F$ statistic for the excluded instrument(s) reported in the table, which remains high across panels.

Our second test of robustness involves estimating reduced form regressions relating travel cost to measures of religiosity. As seen in Table 6, the results of these regressions show that the direct effect of our instrument on religiosity is consistently positive and highly significant. Once again, this test confirms the robustness of our results.

Table 6 about here

Yet another concern might be whether our results depend on the sample of countries included in the surveys. For example, how would the results change if we exclude from the sample the countries that host a center for one of the missionary religions? Likewise, would the result change if we restrict the sample to the "Old World" (i.e., exclude Oceania and W. Hemisphere)? To find the answers to these questions, we ran the same regressions as in Table 4 by excluding from the sample countries that host 
religious centers and by restricting it to countries in the New World. Table 7 shows the resulting estimates of the coefficient of religiosity index (corresponding to column 6 in Table 4). The results (available upon request) are generally consistent if the dependent variable is one of the individual components of the index (i.e., the dependent variables in columns 1-5 in Table 4). As seen in Table 7, the coefficient of religious pluralism remains positive and highly significant in both subsamples. The results confirm that our main result regarding the positive effect of religious pluralism on religiosity is robust across subsamples of data, though of course the magnitude and significance of this effect varies.

Table 7 about here

Finally, we run a falsification test to determine whether the strength of the instrument reflects a genuine effect of proximity to centers of missionary religions or something else. For example, could the results of the first stage simply be due to the cosmopolitan characteristic of these locations or the socioeconomic importance of the surrounding regions in the world stage? To examine this question, we perform a falsification test by running the same first stage analysis for other important cities that serve as placebo centers. Since the instrument depends on the proximity of other countries to these cities, we chose several large cities that are located far away from the centers of missionary religions that were originally used for our analysis to ensure that the results show the effect of their own characteristics rather than their proximity to missionary centers. Specifically, we chose Lagos, New York, São Paulo, Sydney, and Tokyo to serve as placebo centers for our falsification test. ${ }^{20}$

\footnotetext{
${ }^{20}$ We performed the same falsification test for various other cities, with similar results. The results are available upon request.
} 
Table 8 about here

The results of the falsification test are presented in Table 8. As in Table 3, the dependent variable in these regressions is religious pluralism, and the models include the full set of control variables. The first five columns show the regression results estimated separately for each city, listed on top. The coefficient of travel cost thus shows the effect on religious pluralism of being located away from this city. Interestingly, the coefficient is positive and somewhat significant for Tokyo, possibly because of a certain characteristic of its location in the globe, something we are unable to explain. Regardless, the low significance of this effect is still reassuring, especially in light of the fact that the effect is entirely absent for other placebo centers. The coefficients of travel cost are insignificant for Lagos, New York, São Paulo, and Sydney. The coefficient of travel cost to the nearest placebo center, shown in the last column and calculated by using the same procedure as that used for the original instrument, is also insignificant, a more direct and general comparison with the results of our original first stage analysis reported in Table 3. The insignificance of this coefficient and the estimated effects of proximity on religious pluralism from the individual placebo cities indicate that the results of the falsification test support the credibility of our instrument.

\section{Conclusion}

The relationship between religious pluralism and participation in religious activities has long been a topic of interest to sociologists, and has recently attracted the attention of economists. The traditional view has been that pluralism, or diversity of religious options, would undermine religiosity by challenging the authority of any one religion. The application of market principles to religion, however, 
has suggested that the opposite effect may be true-namely, that a more diverse religion market will increase participation by offering "consumers" more and better options. Given these conflicting views, it is desirable to obtain empirical evidence on the relationship between pluralism and religiosity. To date, these studies have provided inconclusive findings. The current paper has contributed to this literature in three ways: first, by providing a theoretical framework that incorporates what we believe is a significant but heretofore neglected factor in assessing the link between pluralism and religiosity-namely, the function of religion for legitimizing government; second, by employing an appropriate data set for empirically evaluating the theory; and third, by offering a novel identification strategy for uncovering the causal effect of religious pluralism.

Our results support the recent economic approach to the relationship between pluralism in the religion market and religious participation. While our OLS analysis apparently showed a significant negative relationship with various indicators of religiosity, estimates that are consistent with traditional views of the effect of pluralism on religiosity, our instrumental variable analysis revealed the actual effect to be in the positive direction for all indicators. Moreover, this finding was consistent with the theoretical prediction of a negative bias arising from the failure to account for the legitimizing function of religion on government.

Overall, we believe that our analysis contributes to our understanding of the complex relationship between pluralism and religiosity by highlighting the importance of the legitimizing function of religion. Economists and sociologists have been unable to reach a consensus in determining the effect of pluralism on religiosity because they have ignored the way the legitimizing function of religion has affected both of these variables. The successful identification of the true causal effect of pluralism in future studies will depend on the appropriate application of estimation strategies. 


\section{References}

Ashraf, Quamrul and Oded Galor. 2013. "The 'Out of Africa' Hypothesis, Human Genetic Diversity, and Comparative Economic Development" American Economic Review, 103(1): 1-46.

Bentzen, Jeanet S. 2018. "Why are some Societies More Religious than Others?" In Advances in the Economics of Religion, ed. Jean-Paul Carvalho, Sriya Iyer, and Jared Rubin, Palgrave Macmillan.

-----. 2019. "Acts of God? Religiosity and Natural Disasters Across Subnational World Districts" Economic Journal, forthcoming.

Berger, Peter L. 1967. The Sacred Canopy; Elements of a Sociological Theory of Religion. Garden City, N.Y.: Doubleday.

Bianchi, Ugo. 1987. "History of Religions." In The Encyclopedia of Religion, ed. Mircea Eliade and Charles J. Adams, 4060-4068. New York: Macmillan.

Brown, Davis and Patrick James. 2015. "Religious Characteristics of States Dataset, Phase 1: Demographics (RCS)" Association of Religion Data Archives.

Cantoni, Davide. 2012. "Adopting a New Religion: The Case of Protestantism in 16th Century Germany" Economic Journal, 122(560): 502-531.

Card, David. 1995. "Using Geographic Variation in College Proximity to Estimate the Return to Schooling." In , ed. Louis N. Christofides, E. Kenneth Grant, and Robert Swidinsky, 201-222: Toronto; Buffalo and London:; University of Toronto Press.

Cesur, Resul and Sadullah Yıldırım. 2018. "Diversity and Religion: Evidence from the Recent African Origin Hypothesis," Working Paper, University of Connecticut.

Chaves, Mark and Philip S. Gorski. 2001. "Religious Pluralism and Religious Participation" Annual Review of Sociology, 27(1): 261.

Cosgel, Metin M. 2016. "Historical Polities Data" University of Connecticut, Working Papers, No: 16.

Cosgel, Metin M., Matthew Histen, Thomas J. Miceli, and Sadullah Yildirim. 2018 (in press). "State and Religion Over Time" Journal of Comparative Economics.

Cosgel, Metin M., Thomas J. Miceli, and Jared Rubin. 2012. "The Political Economy of Mass Printing: Legitimacy and Technological Change in the Ottoman Empire" Journal of Comparative Economics, 40(3): 357-371.

-----. 2012. "Political Legitimacy and Technology Adoption" Journal of Institutional and Theoretical Economics, 168(3): 339-361.

Cosgel, Metin and Thomas J. Miceli. 2009. "State and Religion" Journal of Comparative Economics, 37(3): 402-416.

Dee, Thomas S. 2004. "Are there Civic Returns to Education?" Journal of Public Economics, 88(9-10): 1697-1720. 
Finke, Roger and Rodney Stark. 1988. "Religious Economies and Sacred Canopies: Religious Mobilization in American Cities, 1906" American Sociological Review, 53(1): 41-49.

Fox, Jonathan. 1999. "The Influence of Religious Legitimacy on Grievance Formation by Ethno-Religious Minorities" Journal of Peace Research, 36(3): 289.

Franck, Raphael and Laurence R. lannaccone. 2014. "Religious Decline in the 20th Century West: Testing Alternative Explanations" Public Choice, 159(3-4): 385-414.

Hungerman, Daniel M. 2011. "Rethinking the Study of Religious Markets." In The Oxford Handbook of the Economics of Religion, ed. Rachel M. McCleary, 257-275: Oxford University Press.

lannaccone, Laurence R. 1991. "The Consequences of Religious Market Structure: Adam Smith and the Economics of Religion" Rationality and Society, 3(2): 156-177.

lannaccone, Laurence R., Roger Finke, and Rodney Stark. 1997. "Deregulating Religion: The Economics of Church and State" Economic inquiry, 35(2): 350-364.

Iyer, Sriya. 2016. "The New Economics of Religion" Journal of Economic Literature, 54(2): 395-441.

Johnson, Donald and Jean Johnson. 2007. Universal Religions in World History: The Spread of Buddhism, Christianity, and Islam to 1500. Boston: McGraw-Hill.

Kokosalakis, Nikos. 1985. "Legitimation Power and Religion in Modern Society" Sociological Analysis, 46(4): 367-376.

Kuenen, A. 1882. National Religions and Universal Religions. Lectures Delivered at Oxford and in London, in April and May, 1882. Vol. 1882. London: Edinburgh, Williams and Norgate.

McCleary, R. M. and R. J. Barro. 2006. "Religion and Political Economy in an International Panel" Journal for the Scientific Study of Religion, 45(2): 149-175.

Michalopoulos, Stelios. 2012. "The Origins of Ethnolinguistic Diversity" American Economic Review, 102(4): 1508-1539.

Michalopoulos, Stelios, Alireza Naghavi, and Giovanni Prarolo. 2018. "Trade and Geography in the Spread of Islam" Economic Journal, forthcoming.

Michalopoulos, Stelios and Elias Papaioannou, ed. 2017. The Long Economic and Political Shadow of History. London: CEPR Press.

Montgomery, J. D. 2003. "A Formalization and Test of the Religious Economies Model" American Sociological Review, 68(5): 782-809.

Murnane, Richard J. and John B. Willett. 2011. Methods Matter: Improving Causal Inference in Educational and Social Science Research. Oxford; New York: Oxford University Press.

Müller, F. M. 1978; 1873. Introduction to the Science of Religion. New York: Arno Press.

Naghavi, Alireza and Giuseppe Pignataro. 2015. "Theocracy and Resilience Against Economic Sanctions" Journal of Economic Behavior and Organization, 111: 1-12. 
Norris, Pippa and Ronald Inglehart. 2004. Sacred and Secular: Religion and Politics Worldwide.

Cambridge, UK ; New York: Cambridge University Press.

North, Charles M. and Carl R. Gwin. 2004. "Religious Freedom and the Unintended Consequences of State Religion" Southern Economic Journal, 71(1): 103-117.

Ramachandran, S., O. Deshpande, C. C. Roseman, N. A. Rosenberg, M. W. Feldman, and L. L. CavalliSforza. 2005. "Support from the Relationship of Genetic and Geographic in Human Populations for a Serial Founder Effect Originating in Africa" Proceedings of the National Academy of Sciences of the United States of America, 102(44): 15942-15947.

Rubin, Jared T. 2017. Rulers, Religion, and Riches: Why the West Got Rich and the Middle East did Not. New York, NY: Cambridge University Press.

Sharma, Arvind. 2012. "Religions: Missionary and Non-Missionary." In Problematizing Religious Freedom, ed. Arvind Sharma, 175-195. Vol. 9. New York: Springer.

Stark, Rodney. 1991. "Christianizing the Urban Empire: An Analysis Based on 22 Greco-Roman Cities" Sociological Analysis, 52(1): 77-88.

Stark, Rodney. 2007. Discovering God: The Origins of the Great Religions and the Evolution of Belief. New York: HarperOne.

Voas, D., A. Crockett, and D. V. A. Olson. 2002. "Religious Pluralism and Participation: Why Previous Research is Wrong" American Sociological Review, 67(2): 212-230. 
Figure 1

Religiosity as measured by the World Values Survey

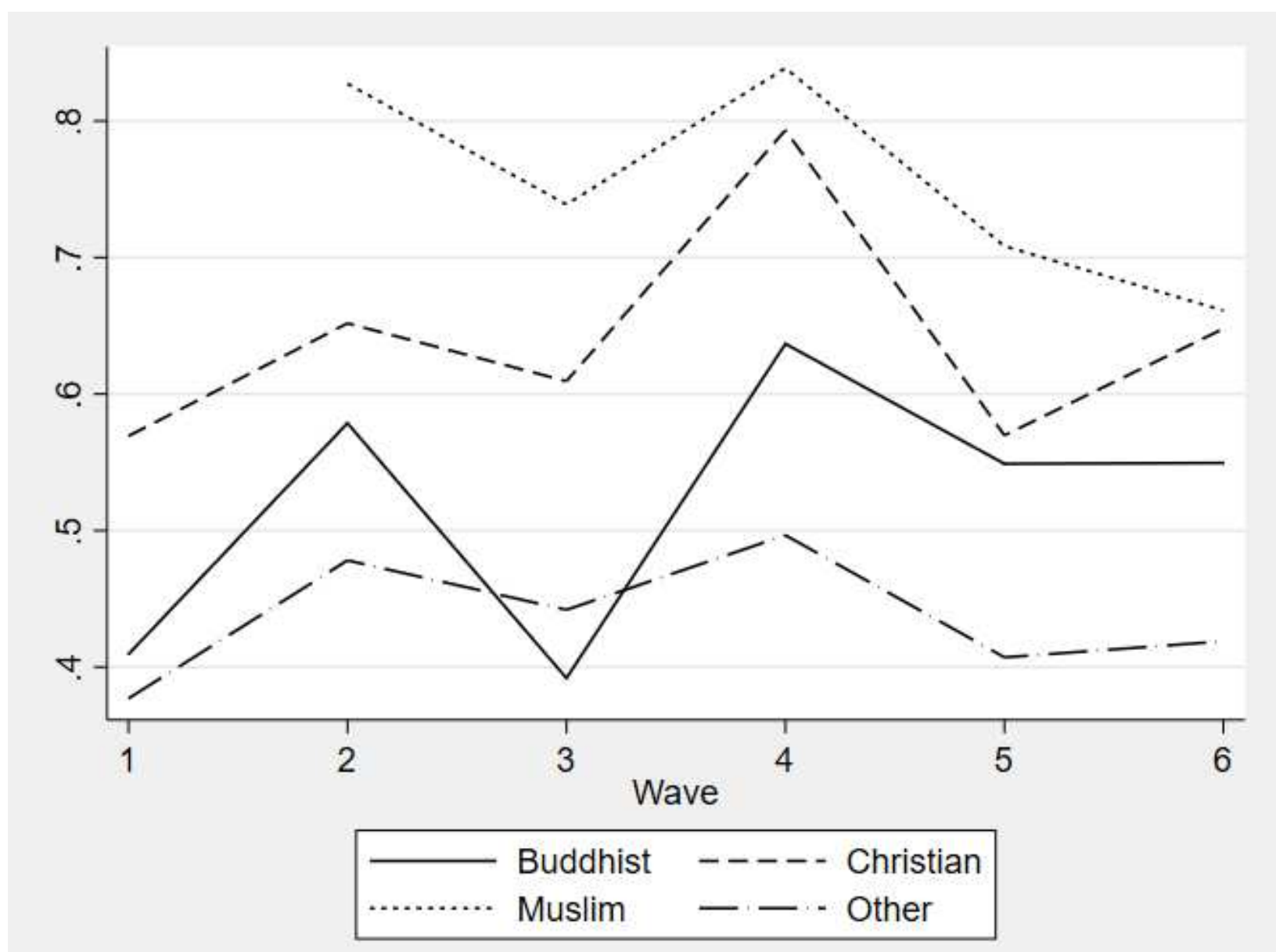

Note: The data show the country level averages of the "Index of Religiosity" by main religion. See the text for a description of the Index. 
Figure 2

Religious Pluralism (Index, 2010)
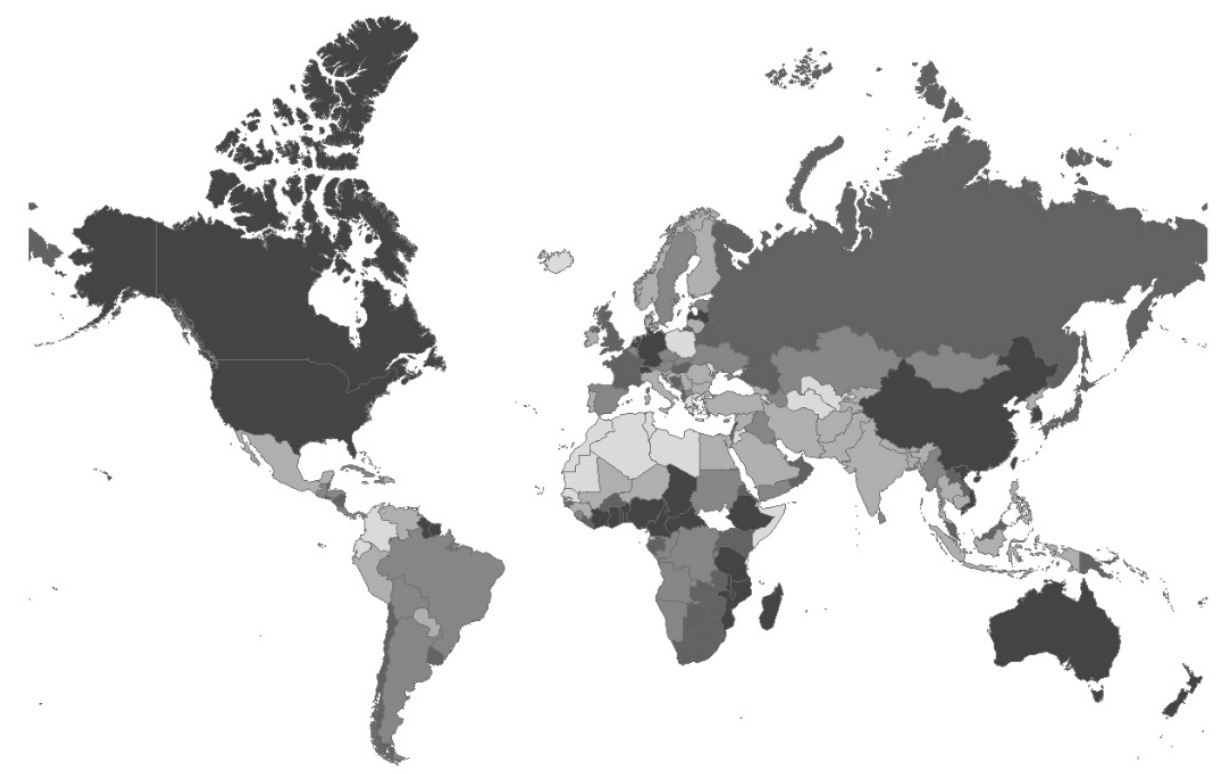

Note: Darker shade corresponds to higher levels of religious pluralism. See the text for the source and description of data. 
Figure 3

Frequency of universal main religions between 1000 and 2000

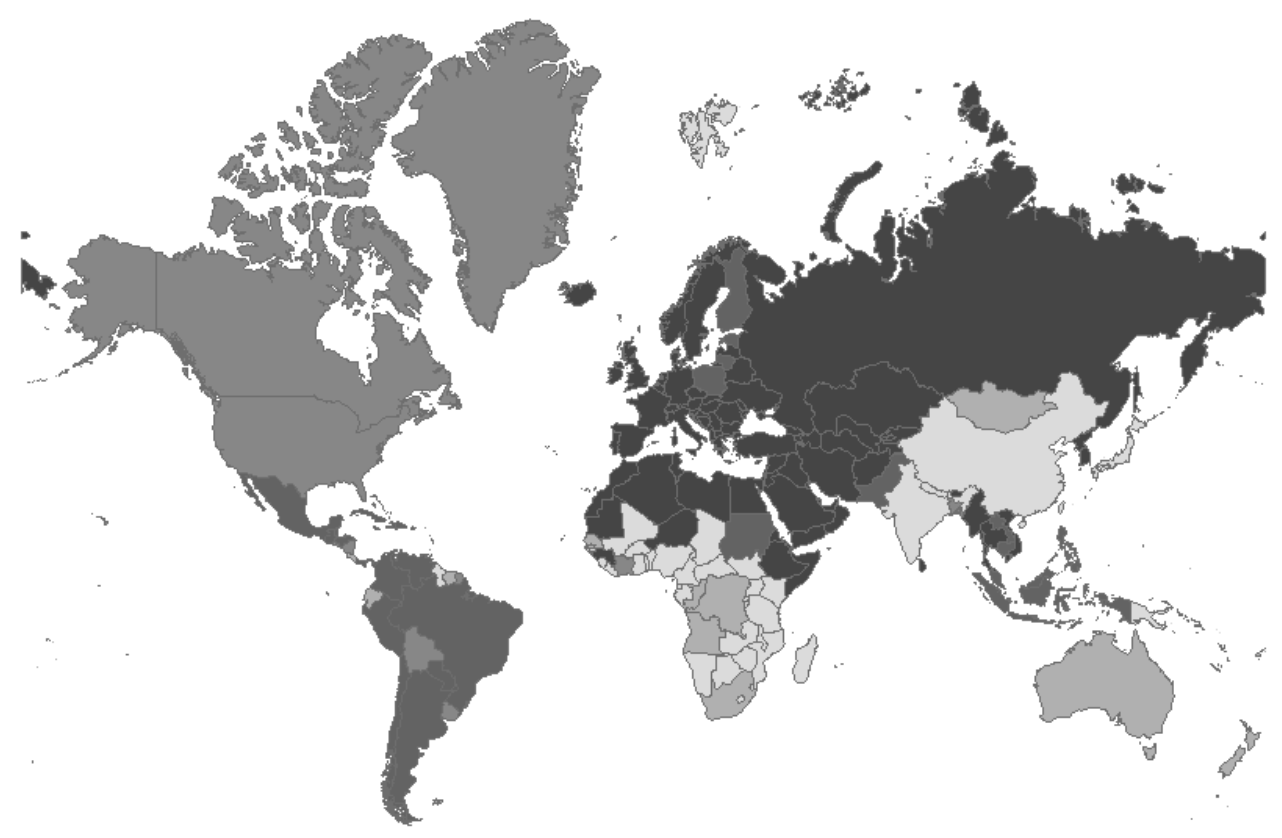

Note: Darker shade corresponds to higher fractions of years in which the main religion was universal during the period between 1000 and 2000. See the text for the source and description of data. 
Table 1

Countries included in the World Values Survey, by main religion

\begin{tabular}{|c|c|c|c|c|c|c|}
\hline \multirow[b]{2}{*}{$\begin{array}{l}\text { WVS } \\
\text { Wave }\end{array}$} & \multirow[b]{2}{*}{ Years } & \multirow[b]{2}{*}{ Total } & \multicolumn{4}{|c|}{ Main Religion } \\
\hline & & & Buddhism & Christianity & Islam & Other \\
\hline 1 & 1981-1984 & 8 & 1 & 6 & 0 & 1 \\
\hline 2 & 1989-1993 & 18 & 1 & 12 & 2 & 3 \\
\hline 3 & 1994-1998 & 54 & 1 & 38 & 7 & 8 \\
\hline 4 & 1999-2004 & 40 & 2 & 17 & 16 & 5 \\
\hline 5 & 2005-2009 & 58 & 2 & 38 & 10 & 8 \\
\hline 6 & 2010-2014 & 60 & 3 & 29 & 20 & 8 \\
\hline
\end{tabular}


Table 2

OLS estimates of influences on religiosity

\begin{tabular}{|c|c|c|c|c|c|c|}
\hline & $\begin{array}{c}\text { (1) } \\
\text { Important in } \\
\text { life: Religion }\end{array}$ & $\begin{array}{c}\text { (2) } \\
\text { Member of } \\
\text { church or } \\
\text { religious } \\
\text { organization }\end{array}$ & $\begin{array}{c}\text { (3) } \\
\text { How often do } \\
\text { you attend } \\
\text { religious } \\
\text { services }\end{array}$ & $\begin{array}{c}\text { (4) } \\
\text { Religious } \\
\text { person }\end{array}$ & $\begin{array}{l}(5) \\
\text { Believe in: } \\
\text { God }\end{array}$ & $\begin{array}{c}\text { (6) } \\
\text { Religiosity } \\
\text { Index (Mean } \\
\text { of 1-5) }\end{array}$ \\
\hline Religious pluralism & $\begin{array}{l}-0.141^{* * *} \\
(0.0459)\end{array}$ & $\begin{array}{l}0.447^{* * *} \\
(0.0776)\end{array}$ & $\begin{array}{l}0.00717 \\
(0.0529)\end{array}$ & $\begin{array}{c}-0.0977^{* * *} \\
(0.0328)\end{array}$ & $\begin{array}{l}-0.0392 \\
(0.0512)\end{array}$ & $\begin{array}{l}-0.00784 \\
(0.0404)\end{array}$ \\
\hline Female & $\begin{array}{l}0.0526^{* * *} \\
(0.00314)\end{array}$ & $\begin{array}{l}0.0185^{* * *} \\
(0.00525)\end{array}$ & $\begin{array}{l}0.00733 \\
(0.0117)\end{array}$ & $\begin{array}{l}0.0450^{* * *} \\
(0.00240)\end{array}$ & $\begin{array}{l}0.0435^{* * *} \\
(0.00474)\end{array}$ & $\begin{array}{l}0.0359^{* * *} \\
(0.00369)\end{array}$ \\
\hline Age & $\begin{array}{l}0.00116^{* * *} \\
(0.000164)\end{array}$ & $\begin{array}{l}0.000437^{* *} \\
(0.000212)\end{array}$ & $\begin{array}{l}0.00109^{* * *} \\
(0.000191)\end{array}$ & $\begin{array}{c}0.000909^{* * *} \\
(0.000110)\end{array}$ & $\begin{array}{c}0.000197 \\
(0.000170)\end{array}$ & $\begin{array}{c}0.000943^{* * *} \\
(0.000134)\end{array}$ \\
\hline Buddhist & $\begin{array}{l}0.109^{* * *} \\
(0.0202)\end{array}$ & $\begin{array}{l}0.0615^{* *} \\
(0.0259)\end{array}$ & $\begin{array}{l}0.161^{* * *} \\
(0.0257)\end{array}$ & $\begin{array}{c}0.0492 \\
(0.0352)\end{array}$ & $\begin{array}{l}-0.0622 \\
(0.0972)\end{array}$ & $\begin{array}{l}0.0906^{* * *} \\
(0.0215)\end{array}$ \\
\hline Muslim & $\begin{array}{l}0.296^{* * *} \\
(0.0253)\end{array}$ & $\begin{array}{l}-0.0176 \\
(0.0355)\end{array}$ & $\begin{array}{l}0.196^{* * *} \\
(0.0267)\end{array}$ & $\begin{array}{l}0.227^{* * *} \\
(0.0232)\end{array}$ & $\begin{array}{l}0.303^{* * *} \\
(0.0394)\end{array}$ & $\begin{array}{l}0.238^{* * *} \\
(0.0221)\end{array}$ \\
\hline Christian & $\begin{array}{l}0.254^{* * *} \\
(0.0163)\end{array}$ & $\begin{array}{l}0.245^{* * *} \\
(0.0198)\end{array}$ & $\begin{array}{l}0.291^{* * *} \\
(0.0169)\end{array}$ & $\begin{array}{l}0.269^{* * *} \\
(0.0162)\end{array}$ & $\begin{array}{l}0.302^{* * *} \\
(0.0329)\end{array}$ & $\begin{array}{l}0.274^{* * *} \\
(0.0147)\end{array}$ \\
\hline $\begin{array}{l}\text { Land suitability for } \\
\text { agriculture }\end{array}$ & $\begin{array}{l}-0.146^{*} \\
(0.0770)\end{array}$ & $\begin{array}{l}0.224^{* *} \\
(0.0944)\end{array}$ & $\begin{array}{c}0.0272 \\
(0.0763)\end{array}$ & $\begin{array}{l}-0.131^{* *} \\
(0.0525)\end{array}$ & $\begin{array}{c}0.124 \\
(0.0792)\end{array}$ & $\begin{array}{l}-0.0401 \\
(0.0592)\end{array}$ \\
\hline Land suitability Gini & $\begin{array}{l}-0.0539 \\
(0.0811)\end{array}$ & $\begin{array}{l}0.503^{* * *} \\
(0.118)\end{array}$ & $\begin{array}{l}0.00985 \\
(0.0929)\end{array}$ & $\begin{array}{l}-0.125^{* *} \\
(0.0625)\end{array}$ & $\begin{array}{c}0.112 \\
(0.0838)\end{array}$ & $\begin{array}{c}0.0261 \\
(0.0665)\end{array}$ \\
\hline Total land area & $\begin{array}{l}7.92 \mathrm{e}-09^{* *} \\
(3.30 \mathrm{e}-09)\end{array}$ & $\begin{array}{l}-1.80 e-09 \\
(4.23 e-09)\end{array}$ & $\begin{array}{l}9.48 \mathrm{e}-09^{* * *} \\
(3.42 \mathrm{e}-09)\end{array}$ & $\begin{array}{c}8.60 \mathrm{e}-09^{* * *} \\
(2.54 \mathrm{e}-09)\end{array}$ & $\begin{array}{c}6.62 \mathrm{e}-09 \\
(5.19 \mathrm{e}-09)\end{array}$ & $\begin{array}{l}5.91 \mathrm{e}-09^{* *} \\
(2.81 \mathrm{e}-09)\end{array}$ \\
\hline Temperature & $\begin{array}{l}0.0159^{* * *} \\
(0.00175)\end{array}$ & $\begin{array}{l}0.0176^{* * *} \\
(0.00244)\end{array}$ & $\begin{array}{l}0.0154^{* * *} \\
(0.00186)\end{array}$ & $\begin{array}{c}0.00579^{* * *} \\
(0.00111)\end{array}$ & $\begin{array}{l}0.0105^{* * *} \\
(0.00180)\end{array}$ & $\begin{array}{l}0.0137^{* * *} \\
(0.00150)\end{array}$ \\
\hline Precipitation & $\begin{array}{l}-0.000234 \\
(0.000206)\end{array}$ & $\begin{array}{c}0.000255 \\
(0.000353)\end{array}$ & $\begin{array}{l}0.000458^{* *} \\
(0.000223)\end{array}$ & $\begin{array}{l}-0.000103 \\
(0.000131)\end{array}$ & $\begin{array}{c}-0.000469^{* *} \\
(0.000202)\end{array}$ & $\begin{array}{l}-0.000202 \\
(0.000172)\end{array}$ \\
\hline $\begin{array}{l}\text { Migratory distance } \\
\text { from East Africa }\end{array}$ & $\begin{array}{l}-0.00406^{* *} \\
(0.00160)\end{array}$ & $\begin{array}{l}-0.00326 \\
(0.00238)\end{array}$ & $\begin{array}{c}-0.00684^{* * *} \\
(0.00165)\end{array}$ & $\begin{array}{l}-0.00167 \\
(0.00108)\end{array}$ & $\begin{array}{c}0.00141 \\
(0.00153)\end{array}$ & $\begin{array}{l}-0.00292^{* *} \\
(0.00134)\end{array}$ \\
\hline Terrain roughness & $\begin{array}{l}0.200^{* * *} \\
(0.0749)\end{array}$ & $\begin{array}{l}-0.125 \\
(0.115)\end{array}$ & $\begin{array}{c}0.120^{*} \\
(0.0688)\end{array}$ & $\begin{array}{l}0.0924^{*} \\
(0.0546)\end{array}$ & $\begin{array}{l}0.195^{* * *} \\
(0.0729)\end{array}$ & $\begin{array}{l}0.109^{* *} \\
(0.0536)\end{array}$ \\
\hline Landlocked & $\begin{array}{l}-0.0369^{*} \\
(0.0205)\end{array}$ & $\begin{array}{c}0.0550 \\
(0.0373)\end{array}$ & $\begin{array}{c}0.000887 \\
(0.0206)\end{array}$ & $\begin{array}{c}0.0144 \\
(0.0146)\end{array}$ & $\begin{array}{l}0.0422^{* *} \\
(0.0206)\end{array}$ & $\begin{array}{r}-0.00588 \\
(0.0164)\end{array}$ \\
\hline $\begin{array}{l}\text { WVS Dummies } \\
\text { Constant }\end{array}$ & $\begin{array}{c}Y \\
0.380^{* * *} \\
(0.0818) \\
\end{array}$ & $\begin{array}{c}Y \\
-0.584^{* * *} \\
(0.0933) \\
\end{array}$ & $\begin{array}{c}Y \\
0.0325 \\
(0.0865) \\
\end{array}$ & $\begin{array}{c}Y \\
0.656^{* * *} \\
(0.0545)\end{array}$ & $\begin{array}{c}Y \\
0.381^{* * *} \\
(0.0833)\end{array}$ & $\begin{array}{c}Y \\
0.145^{* *} \\
(0.0685)\end{array}$ \\
\hline $\begin{array}{l}\text { Observations } \\
R^{2}\end{array}$ & $\begin{array}{c}294,899 \\
0.351\end{array}$ & $\begin{array}{c}220,786 \\
0.225\end{array}$ & $\begin{array}{c}289,018 \\
0.231\end{array}$ & $\begin{array}{c}283,055 \\
0.231\end{array}$ & $\begin{array}{c}197,336 \\
0.264\end{array}$ & $\begin{array}{c}306,620 \\
0.415\end{array}$ \\
\hline
\end{tabular}

Notes:

1. The dependent variables are as stated in the top row. See Section 3 for a description of measures of religiosity and explanatory variables.

2. Omitted category is "No Religion or Adherent of Other Religion".

3. Figures in parentheses are the robust standard errors two-way clustered by country and WVS waves.

4. $* p<0.1 ; * * p<0.05 ; * * * p<0.01$ 
Table 3

Proximity to Universal Religions and Religious Pluralism: First Stage Results

\begin{tabular}{|c|c|}
\hline & Religious Pluralism \\
\hline \multirow[t]{2}{*}{ Travel cost (Walking days) } & $0.00437^{* * *}$ \\
\hline & $(0.000410)$ \\
\hline \multirow[t]{2}{*}{ Land suitability for agriculture } & -0.00604 \\
\hline & $(0.110)$ \\
\hline \multirow[t]{2}{*}{ Land suitability Gini } & -0.154 \\
\hline & $(0.125)$ \\
\hline \multirow[t]{2}{*}{ Total land area } & $1.15 \mathrm{e}-08^{* * *}$ \\
\hline & (3.53e-09) \\
\hline \multirow[t]{2}{*}{ Temperature } & $-0.00767^{* * *}$ \\
\hline & $(0.00161)$ \\
\hline \multirow[t]{2}{*}{ Precipitation } & $0.000761^{* * *}$ \\
\hline & $(0.000275)$ \\
\hline \multirow[t]{2}{*}{ Migratory distance from East Africa } & $-0.0252^{* * *}$ \\
\hline & $(0.00246)$ \\
\hline \multirow[t]{2}{*}{ Terrain roughness } & -0.156 \\
\hline & $(0.107)$ \\
\hline \multirow[t]{2}{*}{ Landlocked } & -0.00385 \\
\hline & $(0.0345)$ \\
\hline \multirow[t]{2}{*}{ Female } & 0.00141 \\
\hline & $(0.00175)$ \\
\hline \multirow[t]{2}{*}{ Age } & $0.000374^{* *}$ \\
\hline & (0.000149) \\
\hline \multirow[t]{2}{*}{ Buddhist } & -0.0353 \\
\hline & $(0.0431)$ \\
\hline \multirow[t]{2}{*}{ Muslim } & $-0.101^{* * *}$ \\
\hline & $(0.0282)$ \\
\hline \multirow[t]{2}{*}{ Christian } & $-0.0746^{* * *}$ \\
\hline & $(0.0138)$ \\
\hline \multirow[t]{2}{*}{ Constant } & $0.626^{* * *}$ \\
\hline & $(0.0950)$ \\
\hline Observations & 309,465 \\
\hline F-statistic for Excluded Instrument & 113.85 \\
\hline$R^{2}$ & 0.436 \\
\hline
\end{tabular}

Notes:

1. Figures in parentheses are the robust standard errors two-way clustered by country and WVS waves.

2. * $p<0.1 ; * * p<0.05 ;{ }^{* * *} p<0.01$ 
Table 4

Religiosity: An Instrumental Variable Analysis

\begin{tabular}{|c|c|c|c|c|c|c|}
\hline & $\begin{array}{l}\text { (1) } \\
\text { Important in } \\
\text { life: Religion }\end{array}$ & $\begin{array}{c}\text { (2) } \\
\text { Member of } \\
\text { church or } \\
\text { religious } \\
\text { organization }\end{array}$ & $\begin{array}{c}\text { (3) } \\
\text { How often do } \\
\text { you attend } \\
\text { religious } \\
\text { services }\end{array}$ & $\begin{array}{c}\text { (4) } \\
\text { Religious } \\
\text { person }\end{array}$ & $\begin{array}{c}\text { (5) } \\
\text { Believe in: } \\
\text { God }\end{array}$ & $\begin{array}{c}\text { (6) } \\
\text { Religiosity } \\
\text { Index (Mean } \\
\text { of 1-5) }\end{array}$ \\
\hline Religious pluralism & $\begin{array}{c}0.370^{* * *} \\
(0.101)\end{array}$ & $\begin{array}{l}1.188^{* * *} \\
(0.157)\end{array}$ & $\begin{array}{c}0.493^{* * *} \\
(0.107)\end{array}$ & $\begin{array}{l}0.146^{* *} \\
(0.0738)\end{array}$ & $\begin{array}{c}0.329^{* * *} \\
(0.119)\end{array}$ & $\begin{array}{l}0.468^{* * *} \\
(0.0940)\end{array}$ \\
\hline Female & $\begin{array}{l}0.0525^{* * *} \\
(0.00336)\end{array}$ & $\begin{array}{l}0.0186^{* * *} \\
(0.00548)\end{array}$ & $\begin{array}{l}0.00716 \\
(0.0116)\end{array}$ & $\begin{array}{l}0.0445^{* * *} \\
(0.00240)\end{array}$ & $\begin{array}{l}0.0432^{* * *} \\
(0.00474)\end{array}$ & $\begin{array}{l}0.0315^{* * *} \\
(0.00402)\end{array}$ \\
\hline Age & $\begin{array}{l}0.00117^{* * *} \\
(0.000194)\end{array}$ & $\begin{array}{c}0.000396 \\
(0.000257)\end{array}$ & $\begin{array}{l}0.00109^{* * *} \\
(0.000219)\end{array}$ & $\begin{array}{c}0.000904^{* * *} \\
(0.000120)\end{array}$ & $\begin{array}{c}0.000215 \\
(0.000193)\end{array}$ & $\begin{array}{c}0.000898^{* * *} \\
(0.000159)\end{array}$ \\
\hline Buddhist & $\begin{array}{l}0.123^{* * *} \\
(0.0426)\end{array}$ & $\begin{array}{c}0.102^{*} \\
(0.0613)\end{array}$ & $\begin{array}{l}0.168^{* * *} \\
(0.0420)\end{array}$ & $\begin{array}{l}0.0597^{* *} \\
(0.0271)\end{array}$ & $\begin{array}{l}-0.0519 \\
(0.0744)\end{array}$ & $\begin{array}{l}0.0936^{* * *} \\
(0.0329)\end{array}$ \\
\hline Muslim & $\begin{array}{l}0.371^{* * *} \\
(0.0403)\end{array}$ & $\begin{array}{c}0.0875 \\
(0.0542)\end{array}$ & $\begin{array}{l}0.264^{* * *} \\
(0.0413)\end{array}$ & $\begin{array}{l}0.266^{* * *} \\
(0.0310)\end{array}$ & $\begin{array}{l}0.357^{* * *} \\
(0.0527)\end{array}$ & $\begin{array}{l}0.291^{* * *} \\
(0.0350)\end{array}$ \\
\hline Christian & $\begin{array}{l}0.274^{* * *} \\
(0.0228)\end{array}$ & $\begin{array}{l}0.283^{* * *} \\
(0.0281)\end{array}$ & $\begin{array}{l}0.312^{* * *} \\
(0.0238)\end{array}$ & $\begin{array}{l}0.281^{* * *} \\
(0.0199)\end{array}$ & $\begin{array}{l}0.315^{* * *} \\
(0.0385)\end{array}$ & $\begin{array}{l}0.299^{* * *} \\
(0.0209)\end{array}$ \\
\hline $\begin{array}{l}\text { Land suitability for } \\
\text { agriculture }\end{array}$ & $\begin{array}{c}-0.125 \\
(0.0939)\end{array}$ & $\begin{array}{l}0.299^{* *} \\
(0.141)\end{array}$ & $\begin{array}{c}0.0551 \\
(0.0941)\end{array}$ & $\begin{array}{l}-0.108^{*} \\
(0.0581)\end{array}$ & $\begin{array}{l}0.197^{* *} \\
(0.0956)\end{array}$ & $\begin{array}{l}0.00959 \\
(0.0707)\end{array}$ \\
\hline Land suitability Gini & $\begin{array}{c}0.0170 \\
(0.0926)\end{array}$ & $\begin{array}{l}0.731^{* * *} \\
(0.163)\end{array}$ & $\begin{array}{l}0.0999 \\
(0.109)\end{array}$ & $\begin{array}{l}-0.0809 \\
(0.0658)\end{array}$ & $\begin{array}{l}0.223^{* *} \\
(0.106)\end{array}$ & $\begin{array}{c}0.122 \\
(0.0757)\end{array}$ \\
\hline Total land area & $\begin{array}{c}1.15 e-10 \\
(4.47 e-09)\end{array}$ & $\begin{array}{c}-1.62 \mathrm{e}-08^{* * *} \\
(6.00 \mathrm{e}-09)\end{array}$ & $\begin{array}{c}2.00 \mathrm{e}-09 \\
(4.48 \mathrm{e}-09)\end{array}$ & $\begin{array}{c}4.78 e-09 \\
(3.23 e-09)\end{array}$ & $\begin{array}{c}1.64 \mathrm{e}-09 \\
(6.33 \mathrm{e}-09)\end{array}$ & $\begin{array}{l}-1.44 e-09 \\
(3.93 e-09)\end{array}$ \\
\hline Temperature & $\begin{array}{l}0.0180^{* * *} \\
(0.00179)\end{array}$ & $\begin{array}{l}0.0206^{* * *} \\
(0.00276)\end{array}$ & $\begin{array}{l}0.0175^{* * *} \\
(0.00186)\end{array}$ & $\begin{array}{c}0.00671^{* * *} \\
(0.00111)\end{array}$ & $\begin{array}{l}0.0124^{* * *} \\
(0.00199)\end{array}$ & $\begin{array}{l}0.0151^{* * *} \\
(0.00157)\end{array}$ \\
\hline Precipitation & $\begin{array}{l}-0.000449^{*} \\
(0.000260)\end{array}$ & $\begin{array}{c}0.000183 \\
(0.000463)\end{array}$ & $\begin{array}{c}0.000324 \\
(0.000264)\end{array}$ & $\begin{array}{l}-0.000183 \\
(0.000160)\end{array}$ & $\begin{array}{c}-0.000546^{* *} \\
(0.000247)\end{array}$ & $\begin{array}{l}-0.000284 \\
(0.000210)\end{array}$ \\
\hline $\begin{array}{l}\text { Migratory distance } \\
\text { from East Africa }\end{array}$ & $\begin{array}{l}-0.00240 \\
(0.00165)\end{array}$ & $\begin{array}{l}-0.00215 \\
(0.00269)\end{array}$ & $\begin{array}{l}-0.00541^{* * *} \\
(0.00192)\end{array}$ & $\begin{array}{l}-0.000789 \\
(0.00116)\end{array}$ & $\begin{array}{c}0.00270 \\
(0.00169)\end{array}$ & $\begin{array}{l}-0.00111 \\
(0.00148)\end{array}$ \\
\hline Terrain roughness & $\begin{array}{l}0.293^{* * *} \\
(0.103)\end{array}$ & $\begin{array}{l}-0.0109 \\
(0.172)\end{array}$ & $\begin{array}{c}0.205^{* *} \\
(0.0934)\end{array}$ & $\begin{array}{c}0.134^{* *} \\
(0.0640)\end{array}$ & $\begin{array}{l}0.247^{* * *} \\
(0.0910)\end{array}$ & $\begin{array}{l}0.166^{* *} \\
(0.0805)\end{array}$ \\
\hline Landlocked & $\begin{array}{c}-0.0597^{* *} \\
(0.0269)\end{array}$ & $\begin{array}{c}0.0263 \\
(0.0519)\end{array}$ & $\begin{array}{l}-0.0188 \\
(0.0248)\end{array}$ & $\begin{array}{l}0.00520 \\
(0.0167)\end{array}$ & $\begin{array}{l}0.0501^{*} \\
(0.0269)\end{array}$ & $\begin{array}{l}-0.0152 \\
(0.0230)\end{array}$ \\
\hline WVS Dummies & $\mathrm{Y}$ & $\mathrm{Y}$ & $Y$ & $\mathrm{Y}$ & $\mathrm{Y}$ & $\mathrm{Y}$ \\
\hline Constant & $\begin{array}{c}0.00676 \\
(0.112)\end{array}$ & $\begin{array}{c}-1.136^{* * *} \\
(0.158)\end{array}$ & $\begin{array}{c}-0.326^{* * *} \\
(0.103)\end{array}$ & $\begin{array}{l}0.445^{* * *} \\
(0.0645)\end{array}$ & $\begin{array}{l}0.0406 \\
(0.130)\end{array}$ & $\begin{array}{c}-0.135 \\
(0.0833)\end{array}$ \\
\hline Observations & 294,899 & 220,786 & 289,018 & 283,055 & 197,336 & 306,620 \\
\hline $\begin{array}{l}\text { Sargan-Hansen } \\
\text { statistic ( } p \text {-value) }\end{array}$ & $2.87(0.58)$ & $1.1(0.77)$ & $5.06(0.41)$ & $2.48(0.78)$ & $0.55(0.97)$ & $2.2(0.82)$ \\
\hline$R^{2}$ & 0.285 & 0.115 & 0.177 & 0.208 & 0.228 & 0.326 \\
\hline
\end{tabular}

Notes:

1. The dependent variables are as stated in the top row. See Section 3 for a description of measures of religiosity. The other endogenous variable is religious pluralism, for which the instrumental variable is the travel cost (walking days) to nearest universal religion center. See Table 3 for first-stage results.

2. Omitted category is "No Religion or Adherent of Other Religion.

3. Figures in parentheses are the robust standard errors two-way clustered by country and WVS waves.

4. $* p<0.1 ; * * p<0.05 ; * * * p<0.01$ 
Table 5

Robustness check: Sensitivity of Results to Controls

\begin{tabular}{|c|c|c|c|c|c|c|}
\hline & $\begin{array}{c}\text { (1) } \\
\text { Important } \\
\text { in life: } \\
\text { Religion }\end{array}$ & $\begin{array}{c}\text { (2) } \\
\text { Member of } \\
\text { church or } \\
\text { religious } \\
\text { organization }\end{array}$ & $\begin{array}{c}\text { (3) } \\
\text { How often } \\
\text { do you } \\
\text { attend } \\
\text { religious } \\
\text { services }\end{array}$ & $\begin{array}{c}\text { (4) } \\
\text { Religious } \\
\text { person }\end{array}$ & $\begin{array}{c}(5) \\
\text { Believe in: } \\
\text { God }\end{array}$ & $\begin{array}{c}\text { (6) } \\
\text { Religiosity } \\
\text { Index } \\
\text { (Mean of 1- } \\
5 \text { ) }\end{array}$ \\
\hline \multicolumn{7}{|l|}{ PANEL A: Baseline } \\
\hline Religious pluralism & $\begin{array}{c}0.370^{* * *} \\
(0.101)\end{array}$ & $\begin{array}{c}1.188^{* * *} \\
(0.157)\end{array}$ & $\begin{array}{c}0.493^{* * *} \\
(0.107)\end{array}$ & $\begin{array}{c}0.146^{* *} \\
(0.0738)\end{array}$ & $\begin{array}{c}0.329^{* * *} \\
(0.119)\end{array}$ & $\begin{array}{l}0.468^{* * *} \\
(0.0940)\end{array}$ \\
\hline
\end{tabular}

First stage F-statistic: 118.85

PANEL B: Includes baseline plus

other country level controls (GDP,

State religion)

\begin{tabular}{lcccccc}
\hline Religious pluralism & $0.416^{* * *}$ & $1.189^{* * *}$ & $0.490^{* * *}$ & 0.122 & $0.393^{* *}$ & $0.482^{* * *}$ \\
& $(0.122)$ & $(0.172)$ & $(0.119)$ & $(0.0798)$ & $(0.155)$ & $(0.109)$
\end{tabular}

First stage F-statistic: 84.53

PANEL C: Includes geographic

controls only

Religious pluralism

$\begin{array}{llllll}0.325^{* * *} & 1.312^{* * *} & 0.530^{* * *} & 0.215^{* * *} & 0.354^{* * *} & 0.509^{* * *} \\ (0.0967) & (0.159) & (0.0957) & (0.0641) & (0.0949) & (0.0811)\end{array}$

First stage F-statistic: 137.74

PANEL D: Baseline with

Instrument=Travel Cost * WVS

Wave Dummies

\begin{tabular}{lcccccc}
\hline Religious pluralism & $0.366^{* * *}$ & $1.180^{* * *}$ & $0.483^{* * *}$ & $0.147^{* *}$ & $0.333^{* * *}$ & $0.469^{* * *}$ \\
& $(0.101)$ & $(0.155)$ & $(0.106)$ & $(0.0721)$ & $(0.117)$ & $(0.0930)$
\end{tabular}

First stage F-statistic: 19.86

Notes:

1. The figures show the coefficient and standard errors of the effect of Religious Pluralism on the dependent variable listed in the top row, estimated by 2SLS analyses that include the control variables stated in each panel's description.

2. Figures in parentheses are the robust standard errors two-way clustered by country and WVS waves.

3. $* p<0.1 ; * *<0.05 ; * * * p<0.01$ 
Table 6

Robustness: Reduced Form Estimates

\begin{tabular}{|c|c|c|c|c|c|c|}
\hline & $\begin{array}{c}\text { (1) } \\
\text { Important in } \\
\text { life: Religion }\end{array}$ & $\begin{array}{c}(2) \\
\text { Member of } \\
\text { church or } \\
\text { religious } \\
\text { organization }\end{array}$ & $\begin{array}{c}(3) \\
\text { How often do } \\
\text { you attend } \\
\text { religious } \\
\text { services }\end{array}$ & $\begin{array}{c}\text { (4) } \\
\text { Religious } \\
\text { person }\end{array}$ & $\begin{array}{l}\text { (5) } \\
\text { Believe in: } \\
\text { God }\end{array}$ & $\begin{array}{c}(6) \\
\text { Religiosity } \\
\text { Index (Mean } \\
\text { of } 1-5 \text { ) }\end{array}$ \\
\hline Travel cost & $\begin{array}{l}0.00160^{* * *} \\
(0.000376)\end{array}$ & $\begin{array}{l}0.00547^{* * *} \\
(0.000554)\end{array}$ & $\begin{array}{l}0.00223^{* * *} \\
(0.000418)\end{array}$ & $\begin{array}{l}0.000620^{* *} \\
(0.000290)\end{array}$ & $\begin{array}{l}0.00144^{* * *} \\
(0.000454)\end{array}$ & $\begin{array}{l}0.00205^{* * *} \\
(0.000342)\end{array}$ \\
\hline All Controls & $Y$ & $Y$ & $Y$ & $Y$ & $Y$ & $Y$ \\
\hline Constant & $\begin{array}{l}0.295^{* * *} \\
(0.0755)\end{array}$ & $\begin{array}{l}-0.205^{* *} \\
(0.0898)\end{array}$ & $\begin{array}{c}0.0543 \\
(0.0716)\end{array}$ & $\begin{array}{l}0.597^{* * *} \\
(0.0518)\end{array}$ & $\begin{array}{l}0.343^{* * *} \\
(0.0778)\end{array}$ & $\begin{array}{c}0.125^{*} \\
(0.0698)\end{array}$ \\
\hline Observations & 294,899 & 220,786 & 289,018 & 283,055 & 197,336 & 306,620 \\
\hline$R^{2}$ & 0.354 & 0.257 & 0.245 & 0.230 & 0.272 & 0.431 \\
\hline
\end{tabular}

Notes:

1. The dependent variables are as stated in the top row.

2. See the text for a description of measures of religiosity and sources of data.

3. Figures in parentheses are the robust standard errors two-way clustered by country and WVS waves.

4. * $p<0.1 ; * *<<0.05 ; * * *<<0.01$ 
Table 7

Robustness: Sub-samples

\begin{tabular}{lcc}
\hline & $\begin{array}{c}(1) \\
\text { Sample excludes } \\
\text { countries that host } \\
\text { centers of universal } \\
\text { religions }\end{array}$ & $\begin{array}{c}\text { Sample excludes the } \\
\text { New World (Oceania, } \\
\text { W. Hemisphere) }\end{array}$ \\
\hline Religious pluralism & $0.407^{* * *}$ & $0.329^{* * *}$ \\
All Controls & $(0.0811)$ & $(0.122)$ \\
& $Y$ & $Y$ \\
\hline Observations & & 236,225 \\
$R^{2}$ & 282,485 & 0.437 \\
\hline
\end{tabular}

Notes:

1. The dependent variable is "Religiosity Index," which is the mean of "Important in life: Religion," "Member of church or religious organization," "How often do you attend religious services," "Religious person," and "Believe in: God."

2. Figures in parentheses are the robust standard errors two-way clustered by country and WVS waves.

3. $* p<0.1 ; * *<<0.05 ; * * * p<0.01$ 
Table 8

Robustness: Placebo Centers

\begin{tabular}{|c|c|c|c|c|c|c|}
\hline & (1) & (2) & (3) & (4) & (5) & (6) \\
\hline & Lagos & New York & São Paulo & Sydney & Tokyo & Nearest Center \\
\hline \multirow[t]{2}{*}{ Travel Cost } & -0.000268 & 0.00142 & -0.00135 & -0.00137 & $0.00178^{*}$ & -0.00276 \\
\hline & $(0.00127)$ & (0.000997) & $(0.000912)$ & $(0.000953)$ & $(0.000981)$ & $(0.00186)$ \\
\hline All Controls & $Y$ & $Y$ & $Y$ & $Y$ & $Y$ & $Y$ \\
\hline \multirow[t]{2}{*}{ Constant } & $0.695^{* * *}$ & $0.606^{* * *}$ & $0.787^{* * *}$ & $0.866^{* * *}$ & $0.531^{* * *}$ & $0.812^{* * *}$ \\
\hline & $(0.169)$ & $(0.174)$ & $(0.189)$ & $(0.197)$ & $(0.164)$ & $(0.191)$ \\
\hline Observations & 309,465 & 309,465 & 309,465 & 309,465 & 309,465 & 309,465 \\
\hline $\mathrm{R}^{2}$ & 0.165 & 0.215 & 0.158 & 0.207 & 0.166 & 0.205 \\
\hline
\end{tabular}

Notes:

1. Figures in parentheses are the robust standard errors two-way clustered by country and WVS waves.

2. $* p<0.1 ; * *<<0.05 ; * * * p<0.01$ 


\section{APPENDIX A: Summary Statistics for Individual-level Variables}

\begin{tabular}{lccccc}
\multicolumn{1}{c}{ Variable } & Mean & Std. Dev. & Min & Max & Observations \\
\hline Important in life: Religion & 0.70 & 0.35 & 0 & 1 & 319588 \\
Member of church or religious organization & 0.28 & 0.39 & 0 & 1 & 245174 \\
How often do you attend religious services & 0.51 & 0.37 & 0 & 1 & 317846 \\
Religious person & 0.83 & 0.28 & 0 & 1 & 310914 \\
Believe in: God & 0.87 & 0.33 & 0 & 1 & 216348 \\
Religiosity Index (Mean of 1-5) & 0.63 & 0.27 & 0 & 1 & 338397 \\
Female & 0.52 & 0.50 & 0 & 1 & 336531 \\
Age & 40.74 & 16.12 & 13 & 99 & 337058 \\
Buddhist & 0.03 & 0.18 & 0 & 1 & 341271 \\
Muslim & 0.21 & 0.41 & 0 & 1 & 341271 \\
Christian & 0.47 & 0.50 & 0 & 1 & 341271 \\
\hline
\end{tabular}




\section{APPENDIX B: Summary Statistics for Country-level Variables}

\begin{tabular}{|c|c|c|c|c|c|c|}
\hline Variable & & Mean & Std. Dev. & Min & Max & $\begin{array}{c}\text { Observatio } \\
\text { ns }\end{array}$ \\
\hline \multirow[t]{3}{*}{ Religious Pluralism } & overall & 0.45 & 0.20 & 0.01 & 0.82 & $\mathrm{~N}=235$ \\
\hline & between & & 0.21 & 0.01 & 0.79 & $\begin{array}{c}\mathrm{n}=96 \\
\mathrm{~T}- \\
\text { bar }=2.447\end{array}$ \\
\hline & within & & 0.03 & 0.32 & 0.58 & 92 \\
\hline \multirow[t]{3}{*}{ State religion } & overall & 0.20 & 0.40 & 0.00 & 1.00 & $N=238$ \\
\hline & between & & 0.43 & 0.00 & 1.00 & $\begin{array}{c}\mathrm{n}=98 \\
\mathrm{~T}- \\
\text { bar }=2.428\end{array}$ \\
\hline & within & & 0.00 & 0.20 & 0.20 & 57 \\
\hline \multirow[t]{3}{*}{ Per capita GDP (log) } & overall & 9.09 & 1.05 & 5.57 & 11.72 & $N=231$ \\
\hline & between & & 1.14 & 5.94 & 11.72 & $\begin{array}{c}\mathrm{n}=93 \\
\mathrm{~T}- \\
\text { bar }=2.483\end{array}$ \\
\hline & within & & 0.26 & 7.96 & 10.46 & 87 \\
\hline \multirow[t]{4}{*}{ Temperature } & overall & 14.87 & 8.22 & -7.93 & 28.64 & $N=231$ \\
\hline & between & & 8.54 & -7.93 & 28.64 & $\begin{array}{c}\mathrm{n}=94 \\
\mathrm{~T}-\end{array}$ \\
\hline & & & & 14.8 & & bar $=2.457$ \\
\hline & within & & 0.00 & 7 & 14.87 & 45 \\
\hline \multirow[t]{4}{*}{ Precipitation } & overall & 79.80 & 52.45 & 2.91 & 233.93 & $N=231$ \\
\hline & between & & 55.73 & 2.91 & 233.93 & $\begin{array}{c}\mathrm{n}=94 \\
\mathrm{~T}-\end{array}$ \\
\hline & & & & 79.8 & & bar $=2.457$ \\
\hline & within & & 0.00 & 0 & 79.80 & 45 \\
\hline \multicolumn{2}{|c|}{$\begin{array}{l}\text { Travel cost to nearest universal religion } \\
\text { center (walking days) }\end{array}$} & 40.96 & 42.57 & 0.03 & 143.52 & 238 \\
\hline \multicolumn{2}{|l|}{ Land suitability for agriculture } & 0.40 & 0.25 & 0.00 & 0.96 & 219 \\
\hline \multicolumn{2}{|l|}{ Land suitability Gini } & 0.39 & 0.24 & 0.00 & 0.87 & 222 \\
\hline \multirow{2}{*}{\multicolumn{2}{|c|}{ Total land area }} & 1510839 & 3035238 & 470. & 1640000 & \\
\hline & & .00 & .00 & 00 & 0.00 & 232 \\
\hline \multicolumn{2}{|l|}{ Migratory distance from East Africa } & 9.63 & 7.43 & 0.00 & 26.77 & 232 \\
\hline \multicolumn{2}{|l|}{ Terrain roughness } & 0.19 & 0.13 & 0.02 & 0.60 & 231 \\
\hline \multicolumn{2}{|l|}{ Landlocked } & 0.16 & 0.36 & 0.00 & 1.00 & 225 \\
\hline
\end{tabular}

